\title{
Divergent effects of methotrexate on the clonal growth of $T$ and $B$ lymphocytes and synovial adherent cells from patients with rheumatoid arthritis
}

Ayako Nakajima, Masayuki Hakoda, Hisashi Yamanaka, Naoyuki Kamatani, Sadao Kashiwazaki

\begin{abstract}
Objective-To define the mechanisms whereby methotrexate (MTX) manifests its effects in patients with rheumatoid arthritis.

Methods-T and B cells from peripheral blood and rheumatoid synovial tissues, synovial adherent cells, and the human fibrosarcoma cell line HT1080 and its mutant (defective in an enzyme in the nucleotide salvage pathway) were tested for clonal growth when cultured with MTX. Normal human fibroblasts and those with a deficiency in a salvage pathway were cultured with MTX in the presence or absence of purine and pyrimidine bases.
\end{abstract}

Results-Clonal growth of $T$ and $B$ cells, but not synovial cells, was inhibited by clinically relevant concentrations of MTX. Slowly proliferating fibroblast lines were resistant to MTX, whereas their rapidly proliferating counterparts were not. However, mutant fibroblast lines deficient in a salvage pathway were sensitive to MTX despite slow proliferation. Similarly, while skin fibroblasts were resistant to MTX, germline mutant fibroblasts deficient in a salvage pathway were sensitive to small concentrations of MTX.

Conclusion-T and B lymphocytes, but not synovial cells, may be the target of MTX in vivo. Resistance to MTX may be associated with slow proliferation and the ability to synthesise nucleotides via salvage pathways. MTX can inhibit proliferation of even slowly growing cells by restricting the supply of nucleotides obtained via a salvage pathway, by removal of purine and pyrimidine bases, or by inducing a deficiency in a salvage pathway. It may be possible to manipulate the therapeutic effect of MTX by adjusting the amounts of purines and pyrimidines available to the cells in vivo.

(Ann Rheum Dis 1996; 55: 237-242)

Many reports in the 1980 s described the efficacy of a low dose weekly pulse regimen of methotrexate (MTX) for the treatment of rheumatoid arthritis (RA), ${ }^{1-3}$ and currently the long term effectiveness of MTX is widely accepted. ${ }^{4-6}$ MTX has been markedly effective in RA patients who had been unresponsive to conventional treatments, ${ }^{17}$ and suppressive effects of MTX on the progression of radiographic changes in RA patients have also been observed. ${ }^{48}$

Various mechanisms have been proposed to account for the beneficial effects of MTX in the management of RA. MTX modulates arachidonic acid metabolism in neutrophils from patients with active RA in such a way that the synthesis, release, and retention of lipoxygenase products are suppressed. ${ }^{9-12}$ MTX suppresses the proliferation of mitogen activated lymphocytes, ${ }^{13-16}$ and inhibits the formation of methyl donor S-adenosylmethionine (SAM) and polyamines, which are important in cell mediated immune reactions. ${ }^{13}$ The activity and production of interleukin-1 may be suppressed by $\mathrm{MTX},{ }^{17-19}$ but the serum concentrations of tumour necrosis factor $\alpha$ and interleukin- 6 are not related to the effectiveness of MTX. ${ }^{20}{ }^{21}$ MTX induces an increase in the intracellular concentration of adenosine, ${ }^{22}{ }^{23}$ and this may be the mechanism for the suppression of neutrophil chemotaxis in a model of acute inflammation. ${ }^{24}$ Despite these various ideas, the mechanisms accounting for the positive effects of MTX in RA treatment remain unclear. ${ }^{25}$

To explóre this issue further at the cellular level, we cloned individual $T$ and $B$ cells in addition to RA synovial adherent cells, and examined the inhibitory effects of MTX on the clonal proliferation of each cell type. Clonal cultures were used in this study in order to simulate the clonal proliferation of lymphocytes in vivo after antigen stimulation. Further, as three cells types (fibroblast-like, macrophagelike, and dendritic cell-like) can be recognised in clonal cultures of synovial adherent cells, ${ }^{26}$ the differential effects of MTX on each cell type can be examined. Finally, we undertook experiments using a mutant cell line deficient in a salvage pathway, to examine the possibility that MTX resistance is mediated by the utilisation of salvage pathways for nucleotide synthesis.

Materials and methods

CELL PREPARATION

Peripheral blood mononuclear cells (PBMC) were obtained from the heparinised blood of healthy volunteers by a standard FicollHypaque density centrifugation method. RA
162 Japan.

Accepted for publication 5 December 1995 
synovial tissues were obtained during surgery from eight patients with active synovitis who fulfilled the 1987 American Rheumatism Association criteria for RA. ${ }^{27}$ Single cells were prepared by enzymatic digestion of the synovial tissues, as described previously. ${ }^{28}$

T CELL CLONING

Utilising techniques described earlier, ${ }^{28}$ we cloned $\mathrm{T}$ cells from PBMC obtained from healthy donors and from single cells prepared from RA synovial tissues obtained during surgical procedures. Briefly, PBMC and synovial single cells were inoculated into 96 well microtitre plates at 1-2 cells/well for PBMC and 2-20 cells/well for synovial single cells, with $x$ irradiated (50 Gy) PBMC $\left(2 \times 10^{4}\right.$ cells/well) and $x$ irradiated (100 Gy) Raji cells $\left(1 \times 10^{4}\right.$ cells/well). The cells were cultured in RPMI 1640 medium supplemented with $10 \%$ fetal calf serum (FCS), $2 \mathrm{mmol} / \mathrm{l}$ L-glutamine, $0.5 \mu \mathrm{g} / \mathrm{ml}$ phytohaemagglutinin-P (Difco, Detroit, $\mathrm{MI})$, and $0.5 \mathrm{ng} / \mathrm{ml}$ recombinant human interleukin-2 (Takeda Chemical Industries, Osaka, Japan). Various concentrations of MTX were added to the culture; 96 wells were prepared for each concentration. After two weeks of culture, each well was observed under an inverted microscope to determine the presence or absence of lymphocyte colonies. Cloning efficiencies were calculated for each concentration of MTX, assuming a Poisson distribution for the number of cells with the potential to form colonies, as follows:

$$
\text { cloning efficiency }(\%)=
$$

$-1 / c \ln$ (number of negative wells / total number of wells) $\times 100(\%)$

where $c=$ number of plated cells/well.

Cloning efficiencies in cultures with MTX were compared with those in control cultures without MTX.

To examine the reverting effects of hypoxanthine and thymidine supplementation on growth inhibition by MTX in T cells, various concentrations of hypoxanthine and thymidine supplement (Gibco, Gaithersburg, MD) and $0 \cdot 1 \mu \mathrm{mol} / 1 \mathrm{MTX}$ were added to the cloning cultures of $\mathrm{T}$ cells.

B CELL CLONING

$B$ cells were cloned from PBMC and RA synovial single cells by procedures described previously, using Epstein-Barr virus (EBV) transformation with some modifications. ${ }^{29}$ CD19 positive cells were positively selected by using CD19 antibody coated magnetic beads (Dynal, Norway) from PBMC of healthy donors. CD19 PBMC and synovial single cells were incubated in the supernatant of the B95-8 cell line for one hour and then inoculated into 96 well plates at 100 cells/well for PBMC and 50-200 cells/well for synovial single cells, with $x$ irradiated PBMC $\left(5 \times 10^{4}\right.$ cells/well $)$. GIT medium (Nihonseiyaku Co Ltd, Tokyo, Japan) supplemented with $10 \%$ FCS was used for the cloning of B cells from single synovial cells; this medium, originally developed for serum free culture of hybridomas, was used because synovial B cell cloning was not successful in RPMI 1640 medium. After two weeks of culture, half of the medium was replaced with fresh medium; 96 wells were prepared for each concentration of MTX.

CLONING OF SYNOVIAL ADHERENT CELLS

For the cloning of synovial adherent cells, RA synovial single cells were inoculated into 96 well flat bottom plates (Coster Corp, Cambridge, MA) at $20-50$ cells/well and cultured in RPMI 1640 supplemented with $10 \% \mathrm{FCS}$ and $2 \mathrm{mmol} / \mathrm{l}$ L-glutamine. Various concentrations of MTX were added to the culture. After two weeks, half of the medium was replaced with fresh medium and the cells were cultured for an additional two weeks.

CELL LINES

To investigate the inhibitory effects of MTX on the clonal proliferation of adherent cells, a human fibrosarcoma cell line (HT1080), normal skin fibroblast cells (SF-TY), and skin fibroblast cells (MiTen) from a patient with Lesch-Nyhan syndrome were obtained from the Japanese Cancer Research Resources Bank (Tsukuba, Japan). To evaluate the role of salvage pathways in MTX resistance, a mutant HT1080 subline (HT1080TG), deficient in the purine salvage enzyme hypoxanthine phosphoribosyltransferase (HPRT), was selected from HT1080 by adding $2.5 \mu \mathrm{g} / \mathrm{ml}$ 6-thioguanine (Wako Pure Chemical Industry, Osaka, Japan).

The cells of HT 1080 were separated by the cloning procedure into large colony forming and small colony forming subpopulations, and cloned in the presence of various concentrations of MTX. For the cloning, HT1080 and HT1080TG were inoculated at 2-20 cells/ well and SF-TY and MiTen at 10-50 cells/ well, into 96 well flat bottom plates. To examine the mechanism for MTX resistance in slowly proliferating (small colony) HT1080 cells, the cells were cloned in medium containing dialysed FCS in place of regular FCS.

STATISTICAL ANALYSIS

Statistical significance of differences between plates with respect to numbers of wells showing cell growth was assayed by $\chi^{2}$ analysis. Differences were considered significant at $\mathrm{p}<0.05$.

\section{Results}

EFFECTS OF MTX ON THE CLONAL GROWTH OF $T$ CELLS

The cloning efficiencies of the $\mathrm{T}$ cells from PBMC ranged from 12.5 to $36 \cdot 8 \%$ (table 1 ). When MTX was added in concentrations greater than $0.05 \mu \mathrm{mol} / 1$, none of the wells was positive for cell growth. Even with MTX 0.025 $\mu \mathrm{mol} / \mathrm{l}$, cloning efficiency was reduced to less than $10 \%$. The clonal growth of T cells from RA synovium also was completely suppressed 
Table 1 Effects of methotrexate on the clonal growth of $T$ cells from normal blood and $R A$ synovium

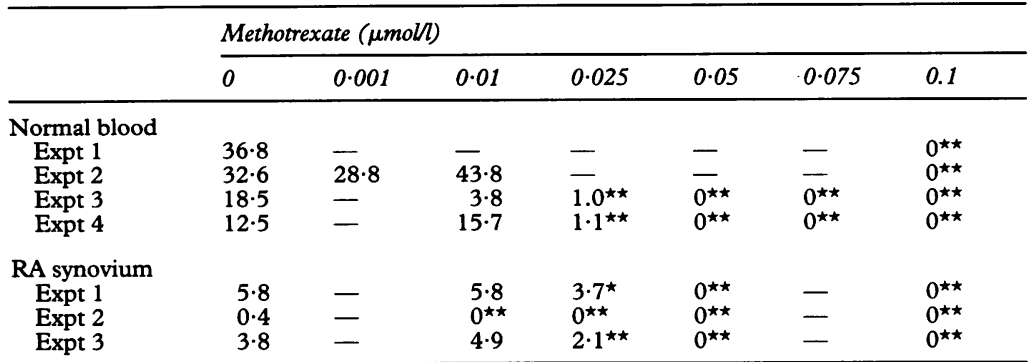

Values represent cloning efficiency (\%).

$-=$ Not done.
Statistical significance of growth inhibition: ${ }^{\star} p<0.05 ;{ }^{\star} \mathrm{p}<0.01$, compared with control (no methotrexate) ( $\chi^{2}$ analysis).

Table 2 Reversal of suppressive effects of methotrexate (MTX) on the T cell growth by hypoxanthine and thymidine supplementation

\begin{tabular}{|c|c|c|c|c|c|c|c|}
\hline \multirow[b]{2}{*}{$\begin{array}{l}\text { Hypoxanthine }(\mu \mathrm{mol} /) \text { : } \\
\text { Thymidine }(\mu \mathrm{mol}) \text { : }\end{array}$} & \multirow{2}{*}{ 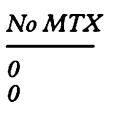 } & \multicolumn{6}{|c|}{ 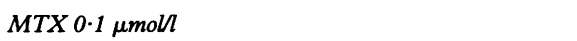 } \\
\hline & & $\begin{array}{l}0 \\
0\end{array}$ & $\begin{array}{l}20 \\
3 \cdot 2\end{array}$ & $\begin{array}{l}100 \\
16\end{array}$ & $\begin{array}{l}200 \\
32\end{array}$ & $\begin{array}{l}500 \\
80\end{array}$ & $\begin{array}{l}1000 \\
160\end{array}$ \\
\hline $\begin{array}{l}\text { Expt } 1 \\
\text { Expt } 2\end{array}$ & $\begin{array}{l}12 \cdot 3 \\
20 \cdot 0\end{array}$ & $\begin{array}{l}0 \\
0\end{array}$ & $\begin{array}{l}0 \\
0\end{array}$ & $\begin{array}{l}5 \cdot 5^{\star \star} \\
6 \cdot 5^{\star \star}\end{array}$ & $\begin{array}{r}9 \cdot 7^{\star \star} \\
19 \cdot 0^{\star \star}\end{array}$ & $\begin{array}{l}9 \cdot 1^{\star \star} \\
17 \cdot 9^{\star \star}\end{array}$ & $\begin{array}{l}9 \cdot 1^{\star \star} \\
6 \cdot 9^{\star \star}\end{array}$ \\
\hline
\end{tabular}

Values represent cloning efficiency (\%).

Statistical significance in the difference of $T$ cell growth in the presence of $0.1 \mu \mathrm{mol} / \mathrm{MTX}$ compared with plates with no hypoxanthine or thymidine: ${ }^{\star \star} \mathrm{p}<0.01\left(\chi^{2}\right.$ analysis).

by low concentrations of MTX (table 1). Thus MTX had potent inhibitory effects on the clonal growth of $T$ cells from two different sources.

Partial rescue by hypoxanthine and thymidine of MTX inhibited T cell growth was obtained by adding the supplement solution at hypoxanthine and thymidine concentrations of 100 and $16 \mu \mathrm{mol} / \mathrm{l}$, respectively (table 2 ). The greatest recovery was observed with hypoxanthine and thymidine concentrations of 200 and $32 \mu \mathrm{mol} / \mathrm{l}$, respectively, at which the rescue effect reached a plateau (table 2 ).

EFFECTS OF MTX ON THE CLONAL GROWTH OF B CELLS

As observed in T cells, MTX had potent inhibitory effects on the clonal growth of $B$ cells cloned directly from CD19 PBMC by EBV transformation; none of the wells was positive for cell growth when MTX was added in concentrations of $0.025 \mu \mathrm{mol} / 1$ or greater (table 3). The clonal growth of synovial B cells was relatively resistant to MTX compared with blood B cells: only partial inhibition was observed with a concentration of $0.025 \mu \mathrm{mol} / 1$

Table 3 Effects of methotrexate (MTX) on the clonal growth of $B$ cells from normal blood and $R A$ synovium

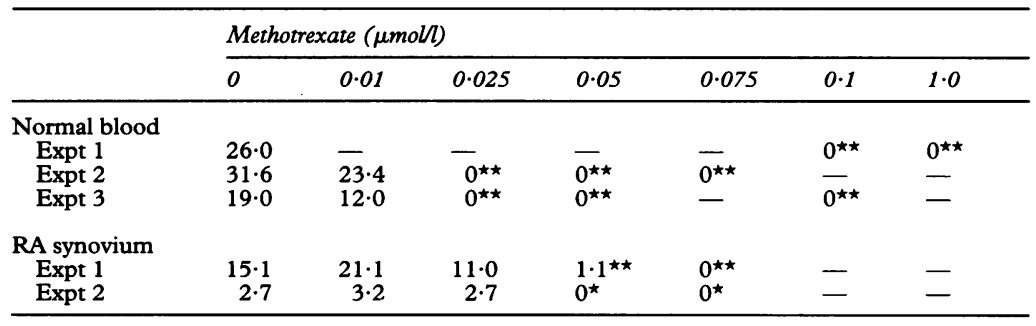

Values represent cloning efficiency $\left(\times 10^{-2} \%\right)$.

$-=$ Not done.
Statistical significance of the growth inhibition in the presence of MTX: ${ }^{\star} p<0.05 ;{ }^{\star} p$ compared with control (no methotrexate) ( $\chi^{2}$ analysis).
MTX (table 3). However, as GIT medium contains $15.0 \mu \mathrm{mol} / 1$ hypoxanthine and 1.5 $\mu \mathrm{mol} / \mathrm{h}$ thymidine, it is likely that these compounds reversed the inhibition of cell growth by MTX.

EFFECTS OF MTX ON THE CLONAL GROWTH OF SYNOVIAL ADHERENT CELLS

MTX had only marginal inhibitory effects on the clonal growth of synovial adherent cells in a concentration of $0.1 \mu \mathrm{mol} / 1$ (table 4 )-the concentration that completely inhibited the growth of T and B cells. Even when the MTX concentration was increased to $1.0 \mu \mathrm{mol} / \mathrm{l}$, $30-50 \%$ of the cells were found to be resistant (table 4), in sharp contrast to the data obtained from $T$ and B cells. Surprisingly, the inhibitory effects of MTX $50 \mu \mathrm{mol} / 1$ on synovial adherent cells were similar to those of MTX $1.0 \mu \mathrm{mol} / 1$ (table 4 ). Thus the clonal growth of synovial adherent cells was found to be highly resistant to MTX compared with that of T and $B$ cells.

EFFECTS OF MTX ON THE CLONAL GROWTH OF A HUMAN FIBROSARCOMA CELL LINE, HT1080 MTX had potent inhibitory effects on the clonal growth of large colony forming HT 1080 cells; the results were similar to those observed in $T$ and $B$ cells (table 5 ). In contrast, and in common with synovial adherent cells, the small colony forming subpopulation was resistant to MTX, suggesting that sensitivity to MTX may relate to the rate of proliferation of the cells, and may not depend on cell type.

When dialysed FCS was substituted for regular FCS in the cloning medium, even the slowly proliferating subpopulations of HT 1080 were quite sensitive to MTX (table 5). In addition, low concentrations of MTX completely inhibited the growth of both rapidly proliferating (large colony) and slowly proliferating (small colony) subpopulations of HT1080TG (table 5).

EFFECTS OF MTX ON THE CLONAL GROWTH OF SKIN FIBROBLASTS

In common with the synovial adherent cells and the slowly proliferating subpopulation of HT 1080 cells, skin fibroblasts were resistant to MTX (table 6). In addition, clonal growth of a fibroblast line (MiTen) from a patient with genetic HPRT deficiency (Lesch-Nyhan syndrome) was completely inhibited by low concentrations of MTX, suggesting again that the salvage enzyme has an important role in MTX resistance (table 6 ).

\section{Discussion}

To investigate the cellular basis for positive effects of MTX in the treatment of RA, we studied the inhibitory effects of MTX on the clonal proliferation of $T$ and $B$ lymphocytes and synovial adherent cells. MTX completely inhibited the clonal growth of $\mathrm{T}$ and $\mathrm{B}$ cells obtained from both peripheral blood and 
Table 4 Effects of methotrexate on the clonal growth of $R A$ synovial adherent cells

\begin{tabular}{lllllllll}
\hline \multicolumn{1}{c}{ Methotrexate $(\mu \mathrm{mol} / \mathrm{l})$} \\
\cline { 2 - 9 } & 0 & 0.01 & 0.1 & 1.0 & 5 & 10 & 20 & 50 \\
\hline Expt 1 (20 cells/well) & 1.72 & - & 1.37 & $0.55^{\star \star}$ & $0.91^{\star}$ & - & - & - \\
Expt 2 (20 cells/well) & - & - & - & 0.26 & 0.55 & 0.38 & 0.05 & 0.16 \\
Expt 3 (50 cells/well) & 0.78 & 0.75 & 0.66 & $0.37^{\star}$ & - & $0.34^{\star \star}$ & - & $0.29^{\star \star}$ \\
\hline
\end{tabular}

Values represent cloning efficiency (\%).

$-=$ Not done.

Statistical significance of the growth inhibition in the presence of methotrexate: ${ }^{\star} p<0.05$ ${ }_{\star} \mathrm{p}<0.01$, compared with control (no methotrexate) ( $\chi^{2}$ analysis).

Table 5 Effects of methotrexate on the clonal growth of human fibrosarcoma cell line HT1080

\begin{tabular}{|c|c|c|c|c|c|c|c|c|c|}
\hline \multirow[t]{2}{*}{ Materials } & & \multirow{2}{*}{$\begin{array}{l}\text { Colony } \\
\text { size }\end{array}$} & \multicolumn{7}{|c|}{ Methotrexate $(\mu \mathrm{mol} /)$} \\
\hline & & & 0 & 0.001 & 0.01 & $0 \cdot 1$ & $1 \cdot 0$ & 10 & 50 \\
\hline HT1080 & $\begin{array}{l}\text { Expt } 1 \\
\text { Expt } 2\end{array}$ & $\begin{array}{l}\text { Large } \\
\text { Small } \\
\text { Large } \\
\text { Small }\end{array}$ & $\begin{array}{r}19 \cdot 5 \\
5.5 \\
8 \cdot 5 \\
4 \cdot 4\end{array}$ & $\begin{array}{l}- \\
\overline{13.0} \\
7 \cdot 3\end{array}$ & $\begin{array}{l}- \\
\overline{1 \cdot 1^{\star \star}} \\
3 \cdot 8\end{array}$ & $\begin{array}{l}0^{\star \star} \\
6 \cdot 1 \\
0^{\star \star} \\
2 \cdot 1\end{array}$ & $\begin{array}{l}0^{\star \star} \\
5 \cdot 5 \\
0^{\star \star} \\
2 \cdot 0\end{array}$ & $\begin{array}{l}- \\
\overline{0 \star \star \star} \\
0 \cdot 5^{\star \star}\end{array}$ & $\begin{array}{l}- \\
\overline{0^{\star \star}} \\
0^{\star \star}\end{array}$ \\
\hline $\begin{array}{l}\text { HT1080 } \\
\text { (dialysed FCS) }\end{array}$ & $\begin{array}{l}\text { Expt } 1 \\
\text { Expt } 2\end{array}$ & $\begin{array}{l}\text { Large } \\
\text { Small } \\
\text { Large } \\
\text { Small }\end{array}$ & $\begin{array}{l}5 \cdot 4 \\
2 \cdot 9 \\
0.9 \\
1 \cdot 2\end{array}$ & $\begin{array}{l}- \\
-\end{array}$ & $\begin{array}{l}0 \cdot 3^{\star \star} \\
2 \cdot 1 \\
0^{\star \star} \\
0 \cdot 3^{\star \star}\end{array}$ & $\begin{array}{l}0^{\star \star} \\
0^{\star \star} \\
0^{\star \star} \\
0^{\star \star}\end{array}$ & $\begin{array}{l}- \\
-\end{array}$ & $\begin{array}{l}- \\
-\end{array}$ & $\begin{array}{l}- \\
-\end{array}$ \\
\hline $\begin{array}{l}\text { HT1080TG } \\
\text { (HPRT deficient) }\end{array}$ & $\begin{array}{l}\text { Expt } 1 \\
\text { Expt } 2\end{array}$ & $\begin{array}{l}\text { Large } \\
\text { Small } \\
\text { Large } \\
\text { Small }\end{array}$ & $\begin{array}{r}43 \cdot 7 \\
30 \cdot 2 \\
18 \cdot 2 \\
2 \cdot 1\end{array}$ & $\begin{array}{r}\overline{-} \\
\overline{13 \cdot 4} \\
4 \cdot 3\end{array}$ & $\begin{array}{l}\overline{-} \\
\overline{0^{\star \star}} \\
0\end{array}$ & $\begin{array}{l}0^{\star \star} \\
0^{\star \star} \\
0^{\star \star} \\
0\end{array}$ & $\begin{array}{l}0^{\star \star} \\
0^{\star \star} \\
- \\
-\end{array}$ & $\begin{array}{l}- \\
\bar{z}\end{array}$ & $\begin{array}{l}- \\
-\end{array}$ \\
\hline
\end{tabular}

Values represent cloning efficiency (\%).

$-=$ Not done. HPRT $=$ Hypoxanthine phosphoribosyltransferase

Statistical significance of the growth inhibition in the presence of methotrexate: ${ }^{\star} p<0.01$ compared with control (no methotrexate) ( $\chi^{2}$ analysis).

Table 6 Effects of methotrexate on the clonal growth of normal and hypoxanthine phosphoribosyltransferase deficient (HPRT-) skin fibroblasts

\begin{tabular}{llll}
\hline & \multicolumn{4}{l}{ Methotrexate $(\mu m o l l)$} \\
\cline { 2 - 4 } & 0 & $0 \cdot 1$ & $1 \cdot 0$ \\
\hline SF-TY (normal) & $3 \cdot 71$ & $3 \cdot 24$ & $2 \cdot 08^{\star \star}$ \\
MiTen (HPRT-) & 0.63 & $0 \star 0^{\star \star}$ & 0. \\
\hline
\end{tabular}

Values represent cloning efficiency (\%).

Statistical significance of the growth inhibition in the presence of methotrexate: ${ }^{\star \star} \mathrm{p}<0.01$, compared with control (no methotrexate) ( $\chi^{2}$ analysis).

rheumatoid synovial tissues, in the low concentrations generally achieved in peripheral blood during treatment with MTX (reported to be $\left.0 \cdot 1-0 \cdot 72 \mu \mathrm{mol} / \mathrm{1}^{30-33}\right)$. As MTX concentrations are reported to be greater in synovial tissues than in peripheral blood, ${ }^{34} \mathrm{MTX}$ treatment is more likely to inhibit proliferation of $\mathrm{T}$ and $\mathrm{B}$ lymphocytes in synovial tissues than in the periphery. In contrast, when MTX was added to the cloning culture of synovial adherent cells, only $50 \%$ inhibition in cloning efficiency was observed at a concentration of $1.0 \mu \mathrm{mol} / \mathrm{l}$, and the inhibitory effects of the drug were not enhanced even in greater concentrations of up to $50 \mu \mathrm{mol} / \mathrm{l}$. Thus it seems that the clonal growth of synovial adherent cells is highly resistant to MTX, compared with that of T and B cells.

Meyer et $a l^{35}$ reported a dose dependent inhibition of the growth of synovial fibroblasts by MTX, which differs from our present findings. They reported $50 \%$ inhibition with a concentration of MTX $0.27 \mu \mathrm{mol} / \mathrm{l}$, while we observed no growth inhibition with MTX $0 \cdot 1$ $\mu \mathrm{mol} / \mathrm{h}$ and approximately $50 \%$ inhibition with MTX $1.0 \mu \mathrm{mol} / 1$ (table 4). These differences may relate to differences in culture methods and procedural techniques. Meyer's group used polyclonal cultures in their experiments, whereas we used only clonal culturing, and they used synovial adherent cells at the first to third passages, whereas we used only fresh synovial single cells; it is possible that cells with greater proliferative capacity become more dominant after cell passage, and such cells could conceivably be more sensitive to the inhibitory effects of MTX.

Sensitivity to MTX appears to be largely dependent on the rate of proliferation of the cells, rather than on cell type, as the clonal growth of a rapidly proliferating (large colony forming) subpopulation of a human fibrosarcoma cell line, HT1080, was completely inhibited by low concentrations of MTX, while that of a slowly proliferating (small colony forming) subpopulation from the same line was not. In the latter line, the apparent resistance of synovial adherent cells to MTX in the present study may be explained by a low rate of proliferation.

Reduced transport of MTX through the cell membranes and amplification of the dihydrofolate reductase (DHFR) gene are known mechanisms for MTX resistance in cultured cells. ${ }^{36-38}$ However, they alone do not explain the MTX resistance of the slowly proliferating subpopulation of HT1080 cells, as deficiency in the purine salvage pathway enzyme HPRT, in the absence of any alteration in membrane permeability or DHFR gene amplification, rendered the cells quite sensitive to MTX. Our data suggest that MTX is incorporated even into slowly proliferating HT1080 cells and inhibits de novo nucleotide synthesis, but that dialysable compound(s) of low molecular weight can be utilised by the salvage pathway to provide amounts of nucleotides sufficient to support the clonal growth of slowly proliferating cells, even in the presence of MTX. In support of this, MTX inhibited the growth of the slowly proliferating HT 1080 cells when the cells were cultured with dialysed FCS, which may be presumed to have been depleted of substrates for the salvage pathway. The dialysable compounds implicated may be either purines or pyrimidines (or both), which are known to serve as a source of nucleotides via salvage pathways. Our finding that small concentrations of MTX inhibited the growth of both rapidly proliferating (large colony) and slowly proliferating (small colony) subpopulations of HT1080TG further supports the notion that the MTX resistance of slowly proliferating subpopulations of HT1080 is related to the salvage pathway.

Equivalent MTX resistance phenomena were observed in skin fibroblasts. Although the clonal growth of normal skin fibroblasts was resistant to MTX, the growth of skin fibroblasts from a patient with Lesch-Nyhan syndrome-a genetic deficiency in HPRT-was inhibited by low concentrations of MTX. These results suggest that nucleotide synthesis through the salvage pathway utilising low concentrations of free bases in FCS may be a general mechanism for MTX resistance in slowly proliferating cells. Apparent resistance of synovial adherent cells to MTX also may be based on similar mechanisms, though the 
inhibitory effect of MTX on the growth of HPRT deficient synovial adherent cells has not been examined (primarily because such biological specimens are not available).

Inhibition of the clonal growth of $T$ cells by MTX was reversed at least partially by the addition of hypoxanthine and thymidine to the culture, confirming that the inhibition of de novo purine and pyrimidine synthesis is the mechanism by which growth is inhibited by MTX. The concentration of hypoxanthine required to achieve $80 \%$ recovery was $200 \mu \mathrm{mol} / \mathrm{h}$ in T cells. The concentration of hypoxanthine in the culture medium (10\% FCS) was approximately $4 \mu \mathrm{mol} / \mathrm{l}$ (measured by HPLC, unpublished data); this concentration appears to have been insufficient to achieve complete reversal of inhibition of growth by MTX in T cells.

The clinical observation ${ }^{39}$ that the efficacy of MTX was decreased by supplementation with an active form of folate (folinic acid), while cessation of folinic acid led to the recovery of MTX effectiveness, suggests that inhibition of DHFR is also implicated in the mechanism for clinical efficacy of MTX. However, in other studies in which smaller doses of folinic acid or folate were administered in different regimens, no reduction in the efficacy of MTX was reported, ${ }^{40-42}$ though a reduction in the side effects of MTX was observed in some. ${ }^{40} 41$ Thus there are discrepancies concerning the effects of folinic acid on the effectiveness of MTX, which seem to be related to differences in the dosage and administration schedule of folinic acid.

Although our in vitro culture system may not be an accurate reflection of in vivo cell proliferation, the data from the present study may have in vivo relevance. The proliferation of $T$ and B lymphocytes, but not synovial adherent cells, may be inhibited in vivo in patients with RA receiving low dose MTX treatment. The in vivo synovial cells may be resistant to MTX, as they utilise small concentrations of free bases in synovial fluid for the synthesis of nucleotides through the salvage pathway. This idea is supported by the observation that the concentration of hypoxanthine in RA synovial fluid is similar to that in our culture medium (approximately 4 $\mu \mathrm{mol} / \mathrm{\Lambda}$, unpublished data). Even when free bases are present in body fluids, they might not be available in quantities sufficient to maintain the proliferation of activated $T$ and $B$ cells. By adjusting the amounts of purines and pyrimidines present in vivo, it may be possible to manipulate the therapeutic effect of MTX. Thus an ability to relate the resistance and sensitivity of various cells in vivo to the availability of purine and pyrimidine compounds may pave the way to a better understanding of, and better adjustment of, the effects of MTX in the treatment of RA.

We thank Dr $M$ W Schein for useful comments on the manuscript. This work was supported by a grant-in-aid to scientific research from the Ministry of Education, Science, and Culture, Japan.

1 Weinblatt M E, Coblyn J S, Fox D A, et al. Efficacy of lowdose of methotrexate in rheumatoid arthritis. $N$ Engl $f$ Med 1985; 312: 818-22.
2 Williams H J, Willkens R F, Samuelson C O Jr, et al. Comparison of low-dose oral pulse methotrexate and placebo in the treatment of rheumatoid arthritis. A controlled clinical trial. Arthritis Rheum 1985; 28: 721-30.

3 Andersen P A, West S G, O'dell J R, Via C S, Claypool R G, Kotzin B L. Weekly pulse methotrexate in rheumatoid arthritis. Clinical and immunologic effects in a randomized, double-blind study. Ann Intern Med 1985; 103: 489-96.

4 Weinblatt M E, Trentham D E, Fraser P A, et al. Long-term prospective trial of low-dose methotrexate in rheumatoid arthritis. Arthritis Rheum 1988; 31: 167-75.

5 Kremer J M, Phelps C T. Long-term prospective study of the use of methotrexate in the treatment of rheumatoid arthritis. Update after a mean of 90 months. Arthritis Rheum 1992; 35: 138-45.

6 Buchbinder R, Hall S, Sambrook P N, et al. Methotrexate therapy in rheumatoid arthritis: a life table review of 587 patients treated in community practice. $\mathcal{F}$ Rheumatol 1993; 20: 639-44.

7 Segal R, Caspi D, Tishler M, Wigler I, Yaron M. Short term effects of low dose methotrexate on the acute phase reaction in patients with rheumatoid arthritis. $\mathcal{F}$ Rheumatol 1989; 16: 914-7.

8 Alarcon G S, Lopez-Mendez A, Walter J, et al. Radiographic evidence of disease progression in methotrexate treated and nonmethotrexate disease modifying antirheumatic drug treated rheumatoid arthritis parients: a metaanalysis. $¥$ Rheumatol 1992; 19: 1868-73.

9 Sperling R I, Coblyn J S, Larkin J K, Benincaso A I, Austen K F, Weinblatt M E. Inhibition of leukotriene B4 synthesis in neutrophils from patients with rheumatoid synthesis in neutrophils from patients with rheumatoid Rheum 1990; 33: 1149-55.

10 Sperling R I, Benincaso A I, Anderson R J, Coblyn J S, Austen K F, Weinblatt M E. Acute and chronic suppression of leukotriene B4 synthesis ex vivo in neutrophils from patients with rheumatoid arthritis beginning treatment with methotrexate. Arthritis Rheum 1992; 35: 376-84.

11 Suarez C R, Pickett W C, Bell D H, McClintock D K, Oronsky A L, Kerwar S S. Effect of low dose methotrexate on neutrophil chemotaxis induced by leukotriene B4 and complement C5a. F Rheumatol 1987; 14: 9-11.

12 Leroux J L, Damon M. Chavis C, Paulet A C D, Blotman $F$. Effects of a single dose of methotrexate on 5 and 12-lipoxygenase products in patients with rheumaand 12-lipoxygenase products in patients

13 Nesher G, Moore T L. The in vitro effects of methotrexate on peripheral blood mononuclear cells. Modulation by methyl donors and spermidine. Arthritis Rheum 1990; 33: 954-9.

14 Oslen N J, Callahan L F, Pincus T. Immunologic studies of rheumatoid arthritis patients treated with methotrexate. Arthritis Rheum 1987; 30: 481-8.

15 Alarcon G S, Schrohenloher R E, Bartolucci A A, Ward J R, Williams H J, Koopman W J. Suppression of rheumatoid factor production by methotrexate in patients with rheumatoid arthritis. Evidence for differential influences of therapy and clinical status on IgM and IgA
rheumatoid factor expression. Arthritis Rheum 1990; 33: rheumatoid

16 Olsen N J, Murray L M. Antiproliferative effects of methotrexate on peripheral blood mononuclear cells. Arthritis Rheum 1989; 32: 378-85.

17 Chang D M, Weinblatt M E, Scher P H. The effects of methotrexate on interleukin 1 in patients with rheumatoid arthritis. $\mathcal{F}$ Rheumatol 1992; 19: 1678-82.

18 Chang D M, Baptiste P, Schur P H. The effect of antirheumatic drugs on interleukin 1 (IL-1) activity and IL-1 and IL-1 inhibitor production by human monocytes. f Rheumatol 1990; 17: 1148-57.

19 Segal R, Mozes E, Yaron M, Tartakovsky B. The effects of methotrexate on the production and activity of methotrexate on the production and acti

20 Barrera P, Boerbooms T A M, Janssen E M, et al. Circulating soluble tumor necrosis factor receptors, interleukin-2 receptors, tumor necrosis factor $\alpha$, and interleukin-6 levels in theumatoid arthritis. Longitudinal evaluation during methotrexate and azathioprine therapy. Arthritis Rheum 1993; 36: 1070-9.

21 Wascher T C, Hermann J, Brezinschek R, et al. Serum levels of interleukin-6 and tumor-necrosis-factor-alpha are not correlated to disease activity in patients with rheumatoid arthritis after treatment with low-dose methotrexate. Eur f Clin Invest 1994; 24: 73-5.

22 Cronstein B N, Naime D, Ostad E. The antiinflammatory mechanism of methotrexate. Increased adenosine release at inflamed sites diminishes leukocyte accumulation in and in vivo model of inflammation. $\mathcal{F}$ Clin Invest 1993; 92: 2675-82.

23 Allegra C J, Drake J C, Jolivet J, Chabner B A. Inhibition of phosphoribosylaminoimidazolecarboxamide transof phosphoribosylaminoimidazolecarboxamide transglutamates. Proc Natl Acad Sci USA 1985; 82: 4881-5.

24 Cronstein B N, Eberle M A, Gruber H E, Levin R I. Methotrexate inhibits neutrophil function by stimulating adenosine release from connective tissue cells. Proc Natl Acad Sci USA 1991; 88: 2441-5.

25 Cronstein B N. Molecular mechanism of methotrexate action in inflammation. Inflammation 1992; 16: 411-23.

26 Goto M, Sasano M, Yamanaka H, et al. Spontaneous production of an interleukin 1-like factor by cloned rheumatoid synovial cells in long-term culture. $\mathcal{f}$ Clin Invest 1987; 80: 786-96. 
27 Arnett F C, Edworthy S M, Bloch D A, et al. The American Rheumatism Association 1987 revised criteria for the classification of rheumatoid arthritis. Arthritis Rheum 1988; 31: 315-24.

28 Hakoda $\mathrm{M}$, Ishimoto $\mathrm{T}$, Yamamoto $\mathrm{K}$, et al. Clonal analysis of $T$ cell infiltrates in synovial tissue of patients with rheumatoid arthritis. Clin Immunol Immunopathol 1990 57: 387-98.

29 Hakoda $M$, Ishimoto $T$, Hayashimoto $S$, et al. Selective infiltration of B cells committed to the production of monoreactive rheumatoid factor in synovial tissue of patients with rheumatoid arthritis. Clin Immunol Immunopathol 1993; 69: 16-22

30 Sinnett M J, Groff G D, Raddatz D A, Franck W A Bertino J S Jr. Methotrexate pharmacokinetics in patients Bertino J $S$ Jr. Methotrexate pharmacokinetics in patients

31 Ahern M, Booth J, Loxton A, McCarthy P, Meffin P, Kevat S. Methotrexate kinetics in rheumatoid arthritis: is there an interaction with nonsteroidal antiinflammatory drugs? F Rheumatol 1988; 15: 1356-60.

32 Jundt J W, Browne B A, Fiocco G P, Steele A D, Mock D. A comparison of low dose methotrexate bioavailability: oral solution, oral tablet, subcutaneous and intramuscular dosing. F Rheumatol 1993; 20: 1845-9.

33 Herman R A, Veng-Pedersen P, Hoffman J, Koehnke R, Furst D E. Pharmacokinetics of low-dose methotrexate in rheumatoid arthritis patients. F Pharm Sci 1989; 78: 165-71.

34 Bologna C, Edno L, Anaya J M, et al. Methotrexate concentrations in synovial membrane and trabecular and cortical bone in rheumatoid arthritis patients. Artiritis Rheum 1994; 37: 1770-3.
35 Meyer F A, Yaron I, Mashiah V, Yaron M. Methotrexate inhibits proliferation but not interleukin 1 stimulated secretory activities of cultured human synovial fibroblasts. Rheumatol 1993; 20. 238-42.

36 Alt $\mathrm{F}$ W, Kellems R E, Bertino J R, Schimke R T. Multiplication of dihydrofolate reductase genes in methotrexate-resistant variants of cultured murine cells. f Biol Chem 1978; 253: 1357-70.

37 Rodenhuis S, Kremer J M, Bertino J R. Increase of dihydrofolate reductase in peripheral blood lymphocyte of rheumatoid arthritis patients treated with low-dose oral methotrexate. Arthritis Rheum 1987; 30: 369-74.

$38 \mathrm{Li} \mathrm{W} W$, Lin J T, Schweitzer B I, Tong W $P$, Niedzwiecki D, Bertino J R. Intrinsic resistance to methotrexate in human soft tissue sarcoma cell lines. Cancer Res 1992; 52: 3908-13.

39 Tishler M, Caspi D, Fishel B, Yaron $M$. The effects of leucovorin (folinic acid) on methotrexate therapy in rheumatoid arthritis patients. Arthritis Rheum 1988; 31 906-8.

40 Morgan S L, Baggott J E, Vaughn W H, et al. The effect of folic acid supplementation on the toxicity of low-dose methotrexate in patients with rheumatoid arthritis. Arthritis Rheum 1990; 33: 9-18.

41 Shiroky J B, Neville C, Esdaile J M, et al. Low-dose methotrexate with leucovorin (folinic acid) in the management of rheumatoid arthritis. Results of a multicenter randomized, double-blind, placebo-controlled trial. Arthritis Rheum 1993; 36: 795-803.

42 Hanrahan P, Russell A S. Concurrent use of folinic acid and methotrexate in rheumatoid arthritis. $₹$ Rheumatol 1988 ; 15: $1078-80$. 